\title{
DELAY MODELS BASED ON SYSTEMS WITH USUAL AND SHIFTED HYPEREXPONENTIAL AND HYPERERLANGIAN INPUT DISTRIBUTIONS
}

Tarasov V. N. - Dr. Sc., Professor, Head of Department of Software and Management in Technical Systems of Volga State University of Telecommunications and Informatics, Samara, Russian Federation.

Bakhareva N. F. - Dr. Sc., Professor, Head of Department of Informatics and Computer Engineering of Volga State University of Telecommunications and Informatics, Samara, Russian Federation.

\begin{abstract}
Context. In the queueing theory, the study of systems with arbitrary laws of the input flow distribution and service time is relevant because it is impossible to obtain solutions for the waiting time in the final form for the general case. Therefore, the study of such systems for particular cases of input distributions is important.

Objective. Getting a solution for the average delay in the queue in a closed form for queuing systems with ordinary and with shifted to the right from the zero point hyperexponential and hypererlangian distributions in stationary mode.

Method. To solve this problem, we used the classical method of spectral decomposition of the solution of the Lindley integral equation. This method allows to obtaining a solution for the average delay for two systems under consideration in a closed form. The method of spectral decomposition of the solution of the Lindley integral equation plays an important role in the theory of systems $\mathrm{G} / \mathrm{G} / 1$. For the practical application of the results obtained, the well-known method of moments of probability theory is used.

Results. For the first time, a spectral decomposition of the solution of the Lindley integral equation for systems with ordinary and with shifted hyperexponential and hyperelangian distributions is obtained, which is used to derive a formula for the average delay in a queue in closed form.

Conclusions. It is proved that the spectral expansions of the solution of the Lindley integral equation for the systems under consideration coincide; therefore, the formulas for the mean delay will also coincide. It is shown that in systems with a delay, the average delay is less than in conventional systems. The obtained expression for the waiting time expands and complements the wellknown incomplete formula of queuing theory for the average delay for systems with arbitrary laws of the input flow distribution and service time. This approach allows us to calculate the average delay for these systems in mathematical packages for a wide range of traffic parameters. In addition to the average waiting time, such an approach makes it possible to determine also moments of higher orders of waiting time. Given the fact that the packet delay variation (jitter) in telecommunications is defined as the spread of the waiting time from its average value, the jitter can be determined through the variance of the waiting time.

KEYWORDS: delayed system, shifted distributions, Laplace transform, Lindley integral equation, spectral decomposition method.
\end{abstract}

\section{ABBREVIATIONS \\ LIE is a Lindley integral equation; \\ QS is a queuing system; \\ PDF is a probability distribution function.}

\section{NOMENCLATURE}

$a(t)$ is a density function of the distribution of time between arrivals;

$A^{*}(s)$ is a Laplace transform of the function $a(t)$; time;

$b(t)$ is a density function of the distribution of service

$B^{*}(s)$ is a Laplace transform of the function $b(t)$;

$c_{\lambda}$ is a coefficient of variation of time between arrivals;

$c_{\mu}$ is a coefficient of variation of service time;

$\mathrm{G}$ is a arbitrary distribution law;

$\mathrm{H}_{2}$ is a hyperexponential distribution of the second order;

$\mathrm{H}_{2}^{-}$is a shifted hyperexponential distribution of the second order;

$\mathrm{HE}_{2}$ is a hypererlangian distribution of the second order;

(C) Tarasov V. N., Bakhareva N. F., 2021

DOI 10.15588/1607-3274-2021-2-6
$\mathrm{HE}_{2}^{-}$is a shifted hypererlangian distribution of the second order;

$\bar{W}$ is an average delay in the queue;

$W^{*}(s)$ is a Laplace transform of delay density function;

$\lambda_{1}, \lambda_{2}$ is a parameters of the hyperexponential distribution law of the input flow;

$\mu_{1}, \mu_{2}$ is a parameters of the hyperelangian distribution law of service time;

$\rho$ is a system load factor;

$\bar{\tau}_{\lambda}$ is a average time between arrivals;

$\bar{\tau}_{\lambda}^{2}$ is a second initial moment of time between arrivals;

$\bar{\tau}_{\mu}$ is an average service time;

$\overline{\tau_{\mu}^{2}}$ is a second initial moment of service time;

$\Phi_{+}(s)$ is a Laplace transform of the PDF of waiting time;

$\psi_{+}(s)$ is a first component of spectral decomposition; 
$\psi_{-}(s)$ is a second component of spectral decomposition.

\section{INTRODUCTION}

In the study of $\mathrm{G} / \mathrm{G} / 1$ systems, an important role is played by the method of spectral decomposition of the solution of the Lindley integral equation (LIE). The most accessible this method with specific examples is described in the classic queueing theory [1].

This article is devoted to the analysis of the QS $\mathrm{H}_{2} / \mathrm{HE}_{2} / 1$ formed by two flows described by the usual and shifted to the right from the zero point by the density functions of the hyperexponential and hypererlangian distribution laws of the second order. In the previous works of the authors, it is clearly shown that in systems formed by shifted distribution laws, with the same load factor as compared with conventional systems, the average delay becomes less.

This is achieved because the coefficients of variation of the arrival $c_{\lambda}$ and service times $c_{\mu}$ for shifted distribution laws become smaller when entering the shift parameter $t_{0}>0$. Thus, the operation of shifting the distribution law transforms ordinary Markov queuing systems into a non-Markov system.

The results of works [2-7] in the domain of QS with shifted distributions together with [1] made it possible to develop the method of spectral expansion of the solution (LIE) into the considered systems $\mathrm{H}_{2} / \mathrm{HE}_{2} / 1$.

Here the superscript "-" will mean the operation of the shift of the distribution law.

In the queueing theory, the studies of $\mathrm{G} / \mathrm{G} / 1$ systems are relevant because they are actively used in modern teletraffic theory; moreover, it is impossible to obtain solutions for such systems in the final form for the general case.

The object of study is the main characteristic - the average waiting time of requirements in the queue of the queueing systems type $\mathrm{G} / \mathrm{G} / 1$.

The subject of study is the average waiting time of requirements in the queue of the $\mathrm{QS} \mathrm{H}_{2} / \mathrm{HE}_{2} / 1$ and $\mathrm{H}_{2}^{-} / \mathrm{HE}_{2}^{-} / 1$. Here the superscript "-" will mean the operation of the shift of the distribution law.

The purpose of the work is obtaining a solution for the average delay of requirements in the queue in closed form for these systems.

\section{PROBLEM STATEMENT}

The paper poses the problem of finding a solution for the average delay of requirements in a queue for QS $\mathrm{H}_{2} / \mathrm{HE}_{2} / 1$ and $\mathrm{H}_{2}^{-} / \mathrm{HE}_{2}^{-} / 1$.

When using the method of spectral decomposition of an LIE solution to determine the average waiting time, we will follow the approach and symbolism of the author of the classical queuing theory [1]. To solve the problem, it is necessary to find the law of waiting time distribution in the system through the spectral decomposition of the

(C) Tarasov V. N., Bakhareva N. F., 2021

DOI 10.15588/1607-3274-2021-2-6 form: $A^{*}(-s) \cdot B *(s)-1=\psi_{+}(s) / \psi_{-}(s)$, where $\psi_{+}(s)$ and $\psi_{-}(s)$ are some fractional rational functions of $s$ that can be factorized. Functions $\psi_{+}(s)$ and $\psi_{-}(s)$ must satisfy the following conditions according to [1]:

1) for $\operatorname{Re}(s)>0$ function $\psi_{+}(s)$ is analytic without zeros in this half-plane;

2) for $\operatorname{Re}(s)<D$ function $\psi_{-}(s)$ is analytic without zeros in this half-plane, where $D$ is some positive constant defined by the condition: $\lim _{t \rightarrow \infty} a(t) / e^{-D t}<\infty$.

In addition, functions $\psi_{+}(s)$ and $\psi_{-}(s)$ must have the following properties:

$$
\lim _{|s| \rightarrow \infty, \operatorname{Re}(s)>0} \frac{\psi_{+}(s)}{s}=1, \lim _{|s| \rightarrow \infty, \operatorname{Re}(s)<D} \frac{\psi_{-}(s)}{s}=-1
$$

To solve the problem, it is necessary first to construct for these systems spectral decompositions of the form $A *(-s) \cdot B *(s)-1=\psi_{+}(s) / \psi_{-}(s)$, taking into account conditions (1), (2).

\section{REVIEW OF THE LITERATURE}

The method of spectral decomposition of the solution of the Lindley integral equation was first presented in detail in the classic queueing theory [1], and was subsequently used in many papers, including [8,9]. A different approach to solving Lindley's equation has been used in Russian language literature. That work used factorization instead of the term "spectral decomposition" and instead of the functions $\psi_{+}(s)$ and $\psi_{-}(s)$ it used factorization components $\omega_{+}(z, t)$ and $\omega_{-}(z, t)$ of the function $1-z \cdot \chi(t)$, where $\chi(t)$ is the characteristic function of a random variable $\xi$ with an arbitrary distribution function $C(t)$, and $z$ is any number from the interval $(-1,1)$. This approach for obtaining results for systems under consideration is less convenient than the approach described and illustrated with numerous examples in [1].

Practical application of the method of spectral decomposition of the LIE solution for studying systems with shifted distribution laws, i.e. systems with time delay, shown in the works of the authors [2-7], as well as in other works.

In the scientific literature, the term "system with delay" does not occur, there is only one term "queues with a delay in time" $[10,11]$. In $[10,11]$ presents the results of the approach of queues to the Internet and mobile services as queues with a delay in time. It is shown that if information is delayed long enough, a Hopf bifurcation can occur, which can cause unwanted fluctuations in the queues. However, it is not known how large the fluctuations are when the Hopf bifurcation 
occurs. This is the first publication in the Englishlanguage journals about queues with a delay.

Approximation methods with respect to distribution laws are described in detail in [9, 13, 14, 23, 24], and new research in queuing theory has recently been carried out in [15-24].

\section{MATERIALS AND METHODS}

Let us first consider the system $\mathrm{H}_{2} / \mathrm{HE}_{2} / 1$, formed by distribution laws with density functions

$$
\begin{gathered}
a(t)=p \lambda_{1} e^{-\lambda_{1} t}+(1-p) \lambda_{2} e^{-\lambda_{2} t}, \\
b(t)=4 q \mu_{1}^{2} t e^{-2 \mu_{1} t}+4(1-q) \mu_{2}^{2} t e^{-2 \mu_{2} t} .
\end{gathered}
$$

The distribution laws (3) and (4) are the most common distributions of non-negative continuous random variables, since they have a wide range of variation of the coefficient of variation.

Then we get

$$
\begin{gathered}
A^{*}(s)=p \frac{\lambda_{1}}{s+\lambda_{1}}+(1-p) \frac{\lambda_{2}}{s+\lambda_{2}} \\
B^{*}(s)=q\left(\frac{2 \mu_{1}}{s+2 \mu_{1}}\right)^{2}+(1-q)\left(\frac{2 \mu_{2}}{s+2 \mu_{2}}\right)^{2} .
\end{gathered}
$$

Then the spectral decomposition of the solution of the LIE for the system $\mathrm{H}_{2} / \mathrm{HE}_{2} / 1$ takes the form

$$
\begin{aligned}
& \frac{\psi_{+}(s)}{\psi_{-}(s)}=\left[p \frac{\lambda_{1}}{\lambda_{1}-s}+(1-p) \frac{\lambda_{2}}{\lambda_{2}-s}\right] \times \\
& \times\left[q\left(\frac{2 \mu_{1}}{2 \mu_{1}+s}\right)^{2}+(1-q)\left(\frac{2 \mu_{2}}{2 \mu_{2}+s}\right)^{2}\right]-1 .
\end{aligned}
$$

The first factor in the right part in square brackets is equal to

$$
\begin{aligned}
& {\left[p \frac{\lambda_{1}}{\lambda_{1}-s}+(1-p) \frac{\lambda_{2}}{\lambda_{2}-s}\right]=\frac{\lambda_{1} \lambda_{2}-\left[p \lambda_{1}+(1-p) \lambda_{2}\right] s}{\left(\lambda_{1}-s\right)\left(\lambda_{2}-s\right)}=} \\
& =\frac{a_{0}-a_{1} s}{\left(\lambda_{1}-s\right)\left(\lambda_{2}-s\right)},
\end{aligned}
$$

where are the intermediate parameters $a_{0}=\lambda_{1} \lambda_{2}, a_{1}=p \lambda_{1}+(1-p) \lambda_{2}$. Similarly, we represent the second factor

$$
\begin{aligned}
& {\left[q\left(\frac{2 \mu_{1}}{2 \mu_{1}+s}\right)^{2}+(1-q)\left(\frac{2 \mu_{2}}{2 \mu_{2}+s}\right)^{2}\right]=} \\
& \quad=\frac{q\left(16 \mu_{1}^{2} \mu_{2}^{2}+16 \mu_{1}^{2} \mu_{2} s+4 \mu_{1}^{2} s^{2}\right)}{\left(2 \mu_{1}+s\right)^{2}\left(2 \mu_{2}+s\right)^{2}}+ \\
& +\frac{(1-q)\left(16 \mu_{1}^{2} \mu_{2}^{2}+16 \mu_{1} \mu_{2}^{2} s+4 \mu_{2}^{2} s^{2}\right)}{\left(2 \mu_{1}+s\right)^{2}\left(2 \mu_{2}+s\right)^{2}}= \\
& =\frac{b_{0}+b_{1} s+b_{2} s^{2}}{\left(2 \mu_{1}+s\right)^{2}\left(2 \mu_{2}+s\right)^{2}},
\end{aligned}
$$

where are the intermediate parameters $b_{0}=16 \mu_{1}^{2} \mu_{2}^{2}$, $b_{1}=16 \mu_{1} \mu_{2}\left[q \mu_{1}+(1-q) \mu_{2}\right], b_{2}=4\left[q \mu_{1}^{2}+(1-q) \mu_{2}^{2}\right]$.

Then the desired expression for the spectral decomposition will be

$$
\begin{aligned}
& \frac{\psi_{+}(s)}{\psi_{-}(s)}=\frac{\left(a_{0}-a_{1} s\right)\left(b_{0}+b_{1} s+b_{2} s^{2}\right)}{\left(\lambda_{1}-s\right)\left(\lambda_{2}-s\right)\left(2 \mu_{1}+s\right)^{2}\left(2 \mu_{2}+s\right)^{2}}- \\
& -\frac{\left(\lambda_{1}-s\right)\left(\lambda_{2}-s\right)\left(2 \mu_{1}+s\right)^{2}\left(2 \mu_{2}+s\right)^{2}}{\left(\lambda_{1}-s\right)\left(\lambda_{2}-s\right)\left(2 \mu_{1}+s\right)^{2}\left(2 \mu_{2}+s\right)^{2}} .
\end{aligned}
$$

The polynomial in the numerator in the right part of the decomposition (5) as a rule always has one zero [1]. In this case, the free term of the decomposition is also 0 : $a_{0} b_{0}-16 \lambda_{1} \lambda_{2} \mu_{1}^{2} \mu_{2}^{2} \equiv 0$. In the numerator of the fraction in the right part of the decomposition a polynomial of the sixth degree was obtained, the coefficients of which are equal to:

$$
\begin{gathered}
c_{0}=a_{0} b_{1}-a_{1} b_{0}+b_{0}\left(\lambda_{1}+\lambda_{2}\right)-16 a_{0} \mu_{1} \mu_{2}\left(\mu_{1}+\mu_{2}\right), \\
c_{1}=a_{0} b_{2}-a_{1} b_{1}-b_{0}-4 a_{0}\left(\mu_{1}^{2}+\mu_{2}^{2}\right)+ \\
+16\left(\lambda_{1}+\lambda_{2}\right)\left(\mu_{1}+\mu_{2}\right) \mu_{1} \mu_{2}-16 a_{0} \mu_{1} \mu_{2}, \\
c_{2}=4\left(\lambda_{1}+\lambda_{2}\right)\left[\left(\mu_{1}+\mu_{2}\right)^{2}+2 \mu_{1} \mu_{2}\right]- \\
-4\left(\mu_{1}+\mu_{2}\right)\left(a_{0}+4 \mu_{1} \mu_{2}\right)-a_{1} b_{2}, \\
c_{3}=4\left(\lambda_{1}+\lambda_{2}\right)\left(\mu_{1}+\mu_{2}\right)-4\left[\left(\mu_{1}+\mu_{2}\right)^{2}+2 \mu_{1} \mu_{2}\right]-a_{0}, \\
c_{4}=\lambda_{1}+\lambda_{2}-4\left(\mu_{1}+\mu_{2}\right) .
\end{gathered}
$$

The coefficients (6) are obtained using the Mathcad symbolic operations, since the numerator of the decomposition (5) even after the introduction of intermediate parameters contains 42 terms. Apparently, the lack of results for the system under consideration is explained by the large laboriousness of the calculations.

We select the polynomial in the numerator of the decomposition (5)

$$
s^{5}-c_{4} s^{4}-c_{3} s^{3}-c_{2} s^{2}-c_{1} s-c_{0},
$$


because determining its roots is the main part of the spectral decomposition method.

The study of polynomial (7) with coefficients (6) using the Vietet formulas confirms the presence of four negative real roots and one positive root, or instead of the first - two negative real roots and two complex conjugate roots with negative real parts.

The coefficient of the polynomial (7) $c_{0}>0$ is always in the case of a stable system, when $0<\rho<1$. Taking into account the minus sign in the polynomial before the coefficient, Vietet formulas do not contradict the fact that there are four negative roots of the polynomial (7).

Denoting the negative roots of the polynomial (7) or their negative real parts for convenience through $-s_{1},-s_{2},-s_{3},-s_{4}$, and the positive root through $s_{5}$, the relation $\psi_{+}(s) / \psi_{-}(s)$ can be finally decomposed into the following factors:

$$
\frac{\psi_{+}(s)}{\psi_{-}(s)}=\frac{-s\left(s+s_{1}\right)\left(s+s_{2}\right)\left(s+s_{3}\right)\left(s+s_{4}\right)\left(s-s_{5}\right)}{\left(\lambda_{1}-s\right)\left(\lambda_{2}-s\right)\left(2 \mu_{1}+s\right)^{2}\left(2 \mu_{2}+s\right)^{2}}
$$

Now we build the functions $\psi_{+}(s)$ and $\psi_{-}(s)$ taking into account the conditions (1) and (2):

$$
\psi_{+}(s)=\frac{s\left(s+s_{1}\right)\left(s+s_{2}\right)\left(s+s_{3}\right)\left(s+s_{4}\right)}{\left(2 \mu_{1}+s\right)^{2}\left(2 \mu_{2}+s\right)^{2}}
$$

because the zeros of the polynomial (7): $s=0$, $-s_{1},-s_{2},-s_{3},-s_{4}$ and double poles $s=-2 \mu_{1}$, $s=-2 \mu_{2}$ lie in the half-plane $\operatorname{Re}(s) \leq 0$,

$$
\psi_{-}(s)=-\frac{\left(\lambda_{1}-s\right)\left(\lambda_{2}-s\right)}{\left(s-s_{5}\right)},
$$

because its zeros and the pole lie in the region $\operatorname{Re}(\mathrm{s})>D$ defined by condition (1).

The fulfillment of conditions (1) and (2) for functions $\psi_{+}(s)$ and $\psi_{-}(s)$ is obvious, which is also confirmed by figure 1 .

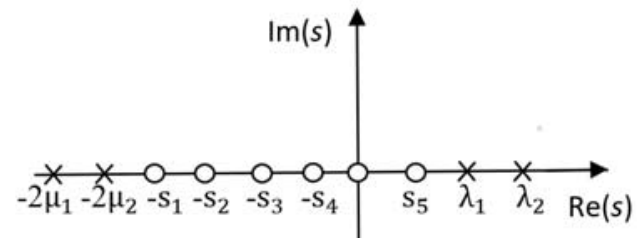

Figure $1-$ Zeros and poles of the function $\psi_{+}(s) / \psi_{-}(s)$ for the system $\mathrm{H}_{2} / \mathrm{HE}_{2} / 1$

When constructing these functions, it is more convenient to mark the zeros and poles of the relation $\psi_{+}(s) / \psi_{-}(s)$ on the complex $s-$ plane to eliminate errors in the construction of the functions $\psi_{+}(s)$ and $\psi_{-}(s)$. In Figure 1, the poles are marked with crosses, and zeros are indicated by circles.
According to the method of spectral decomposition, the constant $K$ is determined from the condition:

$$
K=\lim _{s \rightarrow 0} \frac{\psi_{+}(s)}{s}=\frac{s_{1} s_{2} s_{3} s_{4}}{16 \mu_{1}^{2} \mu_{2}^{2}} .
$$

The constant $K$ determines the probability that the demand entering the system finds it free. Through $\psi_{+}(s)$ and the constant $K$ we define

$$
\Phi_{+}(s)=\frac{K}{\psi_{+}(s)}=\frac{s_{1} s_{2} s_{3} s_{4}\left(s+2 \mu_{1}\right)^{2}\left(s+2 \mu_{2}\right)^{2}}{16 s \mu_{1}^{2} \mu_{2}^{2}\left(s+s_{1}\right)\left(s+s_{2}\right)\left(s+s_{3}\right)\left(s+s_{4}\right)} .
$$

From here we get

$$
W^{*}(s)=s \cdot \Phi_{+}(s)=\frac{s_{1} s_{2} s_{3} s_{4}\left(s+2 \mu_{1}\right)^{2}\left(s+2 \mu_{2}\right)^{2}}{16 \mu_{1}^{2} \mu_{2}^{2}\left(s+s_{1}\right)\left(s+s_{2}\right)\left(s+s_{3}\right)\left(s+s_{4}\right)} \cdot
$$

The desired average waiting time in the queue is equal to the value of the derivative of the Laplace transform (9) of the density function with a minus sign at the point $s=0$ :

$$
-\left.\frac{d W^{*}(s)}{d s}\right|_{s=0}=\frac{1}{s_{1}}+\frac{1}{s_{2}}+\frac{1}{s_{3}}+\frac{1}{s_{4}}-\frac{1}{\mu_{1}}-\frac{1}{\mu_{2}} .
$$

Finally for QS $\mathrm{H}_{2} / \mathrm{HE}_{2} / 1$

$$
\bar{W}=\frac{1}{s_{1}}+\frac{1}{s_{2}}+\frac{1}{s_{3}}+\frac{1}{s_{4}}-\frac{1}{\mu_{1}}-\frac{1}{\mu_{2}} .
$$

From expression (9) if necessary, we can also determine higher order moments for the waiting time. The second derivative of the transformation (9) at the point $s=0$ gives the second initial moment of the waiting time, which allows us to determine the variance of the waiting time. Taking into account the definition of jitter in telecommunications as the spread of waiting time around its average value [10], we thereby obtain the possibility of determining jitter through variance. This is an important result for analyzing latency sensitive traffic.

We now turn to the study of the $\mathrm{H}_{2} / \mathrm{HE}_{2} / 1$ system with shifted input distributions, i.e. to the system with a delay in time. Such a system, unlike the usual system, we denote $\mathrm{H}_{2}^{-} / \mathrm{HE}_{2}^{-} / 1$. This system will be described by distribution laws:

$$
\begin{gathered}
a(t)=p \lambda_{1} e^{-\lambda_{1}\left(t-t_{0}\right)}+(1-p) \lambda_{2} e^{-\lambda_{2}\left(t-t_{0}\right)}, \\
b(t)=4 q \mu_{1}^{2}\left(t-t_{0}\right) e^{-2 \mu_{1}\left(t-t_{0}\right)}+4(1-q) \mu_{2}^{2}\left(t-t_{0}\right) e^{-2 \mu_{2}\left(t-t_{0}\right)} .
\end{gathered}
$$

Density functions (11) and (12) are shifted to the right from the zero point by the value $t_{0}>0$ of second-order hyperexponential and hyper-Erlang distributions. To find the average waiting time in the queue for this system, we prove the following statement.

Statement. The spectral decompositions $A^{*}(-s) * B^{*}(s)-1=\psi_{+}(s) / \psi_{-}(s)$ of the LIE solution 
for systems $\mathrm{H}_{2}^{-} / \mathrm{HE}_{2}^{-} / 1$ and $\mathrm{H}_{2} / \mathrm{HE}_{2} / 1$ completely coincide and have the form (8), i.e. the spectral decomposition of $A^{*}(-s) * B^{*}(s)-1$ is invariant to the operation of the time shift of the density function.

Proof. For a $\mathrm{H}_{2}^{-} / \mathrm{HE}_{2}^{-} / 1$ system, the spectral decomposition will be:

$$
\begin{aligned}
& \frac{\psi_{+}(s)}{\psi_{-}(s)}=\left[p \frac{\lambda_{1}}{\lambda_{1}-s}+(1-p) \frac{\lambda_{2}}{\lambda_{2}-s}\right] e^{t_{0} s} \times \\
& \times\left[q\left(\frac{2 \mu_{1}}{2 \mu_{1}+s}\right)^{2}+(1-q)\left(\frac{2 \mu_{2}}{2 \mu_{2}+s}\right)^{2}\right] e^{-t_{0} s}-1= \\
& =\left[p \frac{\lambda_{1}}{\lambda_{1}-s}+(1-p) \frac{\lambda_{2}}{\lambda_{2}-s}\right] \times \\
& \times\left[q\left(\frac{2 \mu_{1}}{2 \mu_{1}+s}\right)^{2}+(1-q)\left(\frac{2 \mu_{2}}{2 \mu_{2}+s}\right)^{2}\right]-1 .
\end{aligned}
$$

Here, exponents with opposite signs of exponential functions are reset to zero, and thus the shift operation in the spectral decomposition is leveled. Thus, the spectral decompositions of the solution of the LIE for the two systems under consideration coincide.

Assertion is proved.

Corollary. The formula for the average waiting time for a system with shifted distributions will have exactly the same form as for system with ordinary distributions, but with changed parameters due to a time shift operation [2-7]. Consequently, the average waiting time for systems with lag actually depends on the magnitude of the shift parameter $t_{0}>0$.

Now we define the numerical characteristics, and through them the unknown parameters of the distributions (11) and (12) by the method of moments. To do this, we write their Laplace transforms:

$$
\begin{gathered}
A^{*}(s)=\left[p \frac{\lambda_{1}}{\lambda_{1}+s}+(1-p) \frac{\lambda_{2}}{\lambda_{2}+s}\right] e^{-t_{0} s}, \\
B^{*}(s)=\left[q\left(\frac{2 \mu_{1}}{2 \mu_{1}+s}\right)^{2}+(1-q)\left(\frac{2 \mu_{2}}{2 \mu_{2}+s}\right)^{2}\right] e^{-t_{0} s} .
\end{gathered}
$$

The first derivative of the function with a minus sign at the point $s=0$ gives the values of the $\bar{\tau}_{\lambda}$

$$
\bar{\tau}_{\lambda}=p \lambda_{1}^{-1}+(1-p) \lambda_{2}^{-1}+t_{0},
$$

and the second derivative at the same point gives the $\overline{\tau_{\lambda}^{2}}$ :

$$
\overline{\tau_{\lambda}^{2}}=t_{0}^{2}+2 t_{0}\left[\frac{p}{\lambda_{1}}+\frac{(1-p)}{\lambda_{2}}\right]+2\left[\frac{p}{\lambda_{1}^{2}}+\frac{(1-p)}{\lambda_{2}^{2}}\right] .
$$

Then the value $c_{\lambda}^{2}$

$$
c_{\lambda}^{2}=\frac{\left[\left(1-p^{2}\right) \lambda_{1}^{2}-2 \lambda_{1} \lambda_{2} p(1-q)+p(2-p) \lambda_{2}^{2}\right]}{\left[t_{0} \lambda_{1} \lambda_{2}+(1-p) \lambda_{1}+p \lambda_{2}\right]^{2}} .
$$

By doing the same with distribution (12), we determine the corresponding characteristics for the service time

$$
\begin{gathered}
\bar{\tau}_{\mu}=q \mu_{1}^{-1}+(1-q) \mu_{2}^{-1}+t_{0}, \\
\overline{\tau_{\mu}^{2}}=t_{0}^{2}+2 t_{0}\left[\frac{q}{\mu_{1}}+\frac{(1-q)}{\mu_{2}}\right]+\frac{3}{2}\left[\frac{q}{\mu_{1}^{2}}+\frac{(1-q)}{\mu_{2}^{2}}\right] \\
c_{\mu}^{2}=\frac{\mu_{1}^{2}-2 q \mu_{2}\left(\mu_{1}-\mu_{2}\right)+q(1-2 q)\left(\mu_{1}-\mu_{2}\right)^{2}}{2\left[t_{0} \mu_{1} \mu_{2}+(1-q) \mu_{1}+q \mu_{2}\right]^{2}} .
\end{gathered}
$$

The mechanism for determining the parameters of distributions (3), (4), (11) and (12) using both the first two initial moments and the three initial moments is described in detail in [2] and [3], respectively. Here we give ready-made expressions for these parameters. For distribution (11) unknown parameters are found by expressions

$p=\frac{1}{2} \pm \sqrt{\frac{1}{4}-\frac{\left(\bar{\tau}_{\lambda}-t_{0}\right)^{2}}{2\left[\left(\bar{\tau}_{\lambda}-t_{0}\right)^{2}+c_{\lambda}^{2} \bar{\tau}_{\lambda}^{2}\right]}}, \quad \lambda_{1}=2 p /\left(\bar{\tau}_{\lambda}-t_{0}\right)$, $\lambda_{2}=2(1-p) /\left(\bar{\tau}_{\lambda}-t_{0}\right)$, and for distribution (12) $q=\frac{1}{2} \pm \sqrt{\frac{1}{4}-\frac{3\left(\bar{\tau}_{\mu}-t_{0}\right)^{2}}{8\left[\left(\bar{\tau}_{\mu}-t_{0}\right)^{2}+c_{\mu}^{2} \bar{\tau}_{\mu}^{2}\right]}}, \quad \mu_{1}=2 q /\left(\bar{\tau}_{\mu}-t_{0}\right)$, $\mu_{2}=2(1-q) /\left(\bar{\tau}_{\mu}-t_{0}\right)$.

From these expressions it follows that the shift parameter is limited by the condition $t_{0}<\bar{\tau}_{\mu}<\bar{\tau}_{\lambda}$. In addition, the range of applicability of the system is determined by the non-negativity of two expressions under the square root for $p$ and $q$.

The algorithm for calculating the average waiting time for given input parameters is reduced to the sequential determination of the unknown parameters of distributions (11) and (12). Next, we determine the coefficients of polynomial (7) using the above expressions (6) and find the necessary roots with negative real parts 
$-s_{1},-s_{2},-s_{3},-s_{4}$. Substituting the absolute values of these roots in expression (10), we determine the average waiting time.

The presence of such roots is due to the existence and uniqueness of the spectral decomposition. Conducted numerous experiments only confirm this fact.

\section{EXPERIMENTS}

Tables 1 and 2 below show the calculation data in the Mathcad package for the usual $\mathrm{H}_{2} / \mathrm{HE}_{2} / 1$ system and for the system $\mathrm{H}_{2}^{-} / \mathrm{HE}_{2}^{-} / 1$ with a delay for cases of low, medium and high load $\rho=0,1 ; 0,5 ; 0,9$ for a wide range of variation coefficients of variation $c_{\lambda}, c_{\mu}$ and for the shift parameter $t_{0}$. Results for a usual system are compared with data for a close $\mathrm{H}_{2} / \mathrm{H}_{2} / 1$ system. Dashes in table. 1 means that at such values of the parameters the $\mathrm{H}_{2} / \mathrm{HE}_{2} / 1$ system is not applicable.

The results for the $\mathrm{H}_{2}^{-} / \mathrm{HE}_{2}^{-} / 1$ system with a delay are compared with the results for the conventional system $\mathrm{H}_{2} / \mathrm{HE}_{2} / 1$. The load factor $\rho$ in both tables is determined by the ratio of average intervals $\rho=\bar{\tau}_{\mu} / \bar{\tau}_{\lambda}$. The calculations used the normalized service time $\bar{\tau}_{\mu}=1$.

The results for the $\mathrm{H}_{2} / \mathrm{HE}_{2} / 1$ and $\mathrm{H}_{2} / \mathrm{H}_{2} / 1$ systems coincide to whole parts, but the range of service parameters for the first system is wider than that of the second.

The $\mathrm{H}_{2}^{-} / \mathrm{HE}_{2}^{-} / 1 \mathrm{~s}$ ystem is applicable for small values of the coefficients of variation, in particular, when $\rho=0,9 \quad c_{\lambda}=0,2$ and $t_{0}=0,99$, the average delay is only a $\bar{W}=0,187$ few units of time.

Table 1 - Results of experiments for QS $\mathrm{H}_{2} / \mathrm{HE}_{2} / 1$ and $\mathrm{H}_{2} / \mathrm{HE}_{2} / 1$

\begin{tabular}{|c|c|c|c|}
\hline \multicolumn{2}{|c|}{ Input parameters } & \multicolumn{2}{c|}{ Average delay } \\
\hline \multirow{4}{*}{$\rho$} & $\left(c_{\lambda}, c_{\mu}\right)$ & $\begin{array}{c}\text { For QS } \\
\mathrm{H}_{2} / \mathrm{HE}_{2} / 1\end{array}$ & $\begin{array}{c}\text { For QS } \\
\mathrm{H}_{2} / \mathrm{H}_{2} / 1\end{array}$ \\
\hline \multirow{4}{*}{0,1} & $(1 ; 0.71)$ & 0.086 & - \\
\cline { 2 - 4 } & $(1 ; 1)$ & 0.111 & 0.111 \\
\cline { 2 - 4 } & $(2 ; 2)$ & 0.446 & 0.445 \\
\cline { 2 - 4 } & $(4 ; 4)$ & 1.791 & 1.779 \\
\cline { 2 - 4 } & $(8 ; 8)$ & 7.173 & 7.112 \\
\hline \multirow{4}{*}{0,5} & $(1 ; 0.71)$ & 0.755 & - \\
\cline { 2 - 4 } & $(1 ; 1)$ & 1.000 & 1.000 \\
\cline { 2 - 4 } & $(2 ; 2)$ & 4.043 & 4.044 \\
\cline { 2 - 4 } & $(4 ; 4)$ & 16.235 & 16.129 \\
\hline \multirow{4}{*}{0,9} & $(8 ; 8)$ & 64.844 & 64.178 \\
\cline { 2 - 4 } & $(1 ; 0.71)$ & 6.771 & - \\
\cline { 2 - 4 } & $(1 ; 1)$ & 9.075 & 9.000 \\
\cline { 2 - 4 } & $(2 ; 2)$ & 36.169 & 36.200 \\
\cline { 2 - 4 } & $(4 ; 4)$ & 144.773 & 144.833 \\
\hline
\end{tabular}

(C) Tarasov V. N., Bakhareva N. F., 2021

DOI 10.15588/1607-3274-2021-2-6
Table 2- Results of experiments for QS $\mathrm{H}_{2}^{-} / \mathrm{HE}_{2}^{-} / 1$ and $\mathrm{H}_{2} / \mathrm{HE}_{2} / 1$

\begin{tabular}{|c|c|c|c|c|c|}
\hline \multicolumn{2}{|c|}{ Input parameters } & \multicolumn{4}{|c|}{ Average delay } \\
\hline \multirow{2}{*}{$\rho$} & \multirow{2}{*}{$\left(c_{\lambda} ; c_{\mu}\right)$} & \multicolumn{3}{|c|}{ For QS $\mathrm{H}_{2}^{-} / \mathrm{HE}_{2}^{-} / 1$} & \multirow{2}{*}{$\begin{array}{c}\text { For QS } \\
\mathrm{H}_{2} / \mathrm{HE}_{2} / 1\end{array}$} \\
\hline & & $t_{0}=0.99$ & $t_{0}=0.5$ & $t_{0}=0.01$ & \\
\hline \multirow{5}{*}{0.1} & $(1 ; 0.71)$ & 0.03 & 0.04 & 0.09 & 0.09 \\
\hline & $(1 ; 1)$ & 0.06 & 0.07 & 0.11 & 0.11 \\
\hline & $(2 ; 2)$ & 0.23 & 0.36 & 0.44 & 0.45 \\
\hline & $(4 ; 4)$ & 0.93 & 1.56 & 1.79 & 1.79 \\
\hline & $(8 ; 8)$ & 3.74 & 6.38 & 7.16 & 7.17 \\
\hline \multirow{5}{*}{0.5} & $(1 ; 0.71)$ & 0.26 & 0.48 & 0.75 & 0.76 \\
\hline & $(1 ; 1)$ & 0.51 & 0.75 & 0.99 & 1.00 \\
\hline & $(2 ; 2)$ & 2.04 & 3.15 & 4.03 & 4.04 \\
\hline & $(4 ; 4)$ & 8.15 & 12.73 & 16.17 & 16.24 \\
\hline & $(8 ; 8)$ & 32.62 & 51.07 & 64.58 & 64.84 \\
\hline \multirow{5}{*}{0.9} & $(1 ; 0.71)$ & 2.49 & 6.00 & 6.77 & 6.77 \\
\hline & $(1 ; 1)$ & 4.73 & 8.29 & 9.06 & 9.08 \\
\hline & $(2 ; 2)$ & 18.92 & 33.20 & 36.14 & 36.17 \\
\hline & $(4 ; 4)$ & 75.69 & 123.39 & 144.63 & 144.77 \\
\hline & $(8 ; 8)$ & 302.78 & 528.43 & 577.29 & 577.88 \\
\hline
\end{tabular}

\section{RESULTS}

The paper presents the spectral expansions of the solution of the Lindley integral equation for the ordinary system $\mathrm{H}_{2} / \mathrm{HE}_{2} / 1$ and the system with a delay, which are used to derive the formula for the average waiting time in the queue for these systems in closed form.

The operation of the shift in time on the one hand, leads to an increase in system load with a delay. The time shift operation, on the other hand, reduces the variation coefficients of the interval between receipts and the service time of requirements.

Because the average waiting time in the $\mathrm{G} / \mathrm{G} / 1$ system is related to the coefficients of variation of the arrival and service time intervals with the quadratic dependence, the average waiting time in the delay system will be less than in the conventional system with the same load factor.

\section{DISCUSSION}

Thus, the range of change of parameters for the $\mathrm{H}_{2}^{-} / \mathrm{HE}_{2}^{-} / 1$ system is much wider than that of the conventional system $\mathrm{H}_{2} / \mathrm{HE}_{2} / 1$.

It is obvious that the average delay in a system with a delay depends on the shift parameter $t_{0}$.

As one would expect, a decrease in the coefficients of variation and due to the introduction of the shift parameter into the laws of the distributions of the input flow and service time, entails a decrease in the average waiting time in systems with a delay several times. Thus, we expand the range of applicability of the $\mathrm{H}_{2} / \mathrm{HE}_{2} / 1$ system in the teletraffic theory.

The full adequacy of the presented results is confirmed by the fact that when the shift parameter $t_{0}$ tends to zero, the average waiting time in a system with a delay tends to its value in a conventional system. In general, the adequacy of the presented mathematical models of systems is achieved by correctly using the classical method of spectral decomposition of LIE for the considered systems. 
The results obtained extend the theory of systems $\mathrm{G} / \mathrm{G} / 1$ and complement the well-known incomplete formula of queuing theory for the average waiting time.

\section{CONCLUSIONS}

In this work, the problem of deriving a formula for the average delay of requests in the queue for the considered systems is solved.

The scientific novelty of the results is that for the first time the spectral decomposition of the solution of the Lindley integral equation for the considered systems was obtained which are used to derive expression for the average waiting time in the queue for this system in closed form.

These expressions complements and expands the wellknown incomplete formula for the average waiting time in the G/G/1 systems with arbitrary laws of input flow distribution and service time.

The practical significance of the work lies in the fact that the obtained results can be successfully applied in the modern theory of teletraffic, where the delays of incoming traffic packets play a primary role. For this, it is necessary to know the numerical characteristics of the incoming traffic intervals and the service time at the level of the first two moments, which does not cause difficulties when using modern traffic analyzers [10].

Prospects for further research are seen in the continuation of the study of systems of type $\mathrm{G} / \mathrm{G} / 1$ with other common input distributions and in expanding and supplementing the formulas for average waiting time.

\section{ACKNOWLEDGEMENTS}

This work was carried out as part of the author's scientific school "Methods and Models for the Research of Computing Systems and Networks", registered at the Russian Academy of Natural Sciences on 31.03.2015 and was supported by the University of PSUTI.

\section{REFERENCES}

1. Kleinrock L. Queueing Systems, Vol. I: Theory. New York: Wiley, 1975, $417 \mathrm{p}$.

2. Tarasov V. N., Akhmetshina, E. G. The average waiting time in a $\mathrm{H}-2 / \mathrm{H}-2 / 1$ queueing system with delay, Journal of Samara State Technical University, Ser. Physical and Mathematical Sciences, 2018, No. 2, pp. 702-713. DOI: https://doi.org/10.14498/vsgtu1607

3. Tarasov V. N. The analysis of two queuing systems HE2/M/1 with ordinary and shifted input distributions, Radio Electronics, Computer Science, Control, 2019, Vol. 49, No. 2, pp. 71-79. DOI: 10.15588/1607-3274-20192-8

4. Tarasov V. N. Queuing systems with delay, Radio Electronics, Computer Science, Control, 2019, Vol. 50, No. 3, pp. 55-63. DOI: 10.15588/1607-3274-2019-3-7

5. Tarasov V. N., Bakhareva N. F. Comparative analysis of two queuing systems M/HE2/1 with ordinary and with the shifted input distributions, Radio Electronics, Computer Science, Control, 2019, Vol. 51, No. 4, pp. 50-58. DOI: 10.15588/1607-3274-2019-4-5

6. Tarasov V. N. Analysis of H-2/E-2/1 system and her of the analog with shifted input distributions, Radio Electronics,
Computer Science, Control, 2020, Vol. 52, No. 1, pp. 90-97. DOI: 10.15588/1607-3274-2020-1-10

7. Tarasov V. N., Bakhareva N. F. Model of teletraffic based on queueing systems E-2/HE2/1 with ordinary and shifted input distributions, Radio Electronics, Computer Science, Control, 2020, Vol. 53, No. 2, pp. 65-74. DOI: 10.15588/1607-3274-2020-2-7

8. Brannstrom N. A. Queueing Theory analysis of wireless radio systems. Appllied to HS-DSCH. Lulea university of technology, 2004, 79 p.

9. Whitt W. Approximating a point process by a renewal process: two basic methods, Operation Research, 1982, Vol. 30, No. 1, pp. 125-147.

10. Novitzky S., Pender J., Rand R. H., Wesson E. Limiting the oscillations in queues with delayed information through a novel type of delay announcement. Queueing Systems, 2020, Vol. 95, P. 281-330.

11. Novitzky S., Pender J., Rand R. H., Wesson E. Nonlinear Dynamics in Queueing Theory: Determining the Size of Oscillations in Queues with Delay. SIAM J. Appl. Dyn. Syst., 18-1, 2019, Vol. 18, No. 1, pp. 279-311. DOI: https://doi.org/10.1137/18M1170637

12. RFC 3393 [IP Packet Delay Variation Metric for IP Performance Metrics (IPPM)] Available at: https://tools.ietf.org/html/rfc3393. (accessed: 26.02.2016).

13. Myskja A. An improved heuristic approximation for the GI/GI/1 queue with bursty arrivals. Teletraffic and datatraffic in a Period of Change. ITC-13. Elsevier Science Publishers, 1991, pp. 683-688.

14. Aliev T. I. Approximation of Probability Distributions in Queuing Models, Scientific and technical bulletin of information technologies, mechanics and optics, 2013, No. 2, pp. 88-93.

15. Aras A. K., Chen X. \& Liu Y. Many-server Gaussian limits for overloaded non-Markovian queues with customer abandonment, Queueing Systems, 2018, Vol. 89, No. 1, pp. 81-125. DOI: https://doi.org/10.1007/s11134-018-9575-0

16. Jennings O. B. \& Pender J. Comparisons of ticket and standard queues, Queueing Systems, 2016, Vol. 84, No. 1, pp. 145-202. DOI: https://doi.org/10.1007/s11134-0169493-y

17. Gromoll H. C., Terwilliger B. \& Zwart B. Heavy traffic limit for a tandem queue with identical service times, Queueing Systems, 2018, Vol. 89, No. 3, pp. 213-241. DOI: https://doi.org/10.1007/s11134-017-9560-z

18. Legros B. M/G/1 queue with event-dependent arrival rates, Queueing Systems, 2018, Vol. 89, No. 3, pp. 269301. DOI: https://doi.org/10.1007/s11134-017-9557-7

19. Bazhba M., Blanchet J., Rhee CH., et al. Queue with heavy-tailed Weibull service times, Queueing Systems, 2019, Vol. 93, No. 11, pp. 1-32. DOI: https://doi.org/10.1007/s11134-019-09640-z/

20. Adan I., D'Auria B., Kella O. Special volume on 'Recent Developments in Queueing Theory' of the third ECQT conference. Queueing Systems, 2019, Vol. 93, No. 1, pp. 1190. DOI: https://doi.org/10.1007/s11134-019-09630-1

21. Adan I., D'Auria B., Kella O. Special volume on 'Recent Developments in Queueing Theory' of the third ECQT conference: part 2, Queueing Systems, 2019, pp. 1-2. DOI: https://doi.org/10.1007/s11134-019-09637-8

22. Tibi D. Martingales and buffer overflow for the symmetric shortest queue model. Queueing Systems, Vol. 93, 2019, pp. 153-190. DOI: 10.1007/s11134-01909628-9 
23. Jacobovic R., Kella O. Asymptotic independence of regenerative processes with a special dependence structure. Queueing Systems, Vol. 93, 2019, pp. 139-152. DOI: $10.1007 / \mathrm{s} 11134-019-09606-1$
24. Wang L., Kulkarni V. Fluid and diffusion models for a system of taxis and customers with delayed matching. Queueing Systems, 2020, Vol. 96, pp. 101-131. DOI: 10.1007/s11134-020-09659-7

Received 19.01.2021. Accepted 18.04.2021.

УДК 621.391.1:621.395

\section{МОДЕЛІ ЗАТРИМКИ НА БАЗІ СИСТЕМ 3 ЗВИЧАЙНИМИ ТА 3 ЗСУНУТИМИ ГІПЕРЕКСПОНЕНТНИМ ТА ГІПЕРЕРЛАНГІВСЬКИМ ВХІДНИМИ РОЗПОДІЛАМИ}

Тарасов В. Н. - д-р техн. наук, професор, завідувач кафедри програмного забезпечення та управління в технічних системах Поволзького державного університету телекомунікацій та інформатики, РФ.

Бахарєва Н. Ф. - д-р техн. наук, професор, завідувач кафедри інформатики та обчислювальної техніки Поволзького державного університету телекомунікацій та інформатики, РФ.

\section{АНОТАЦЯ}

Актуальність. У теорії масового обслуговування дослідження систем довільними законами розподілів вхідного потоку і часу обслуговування актуальні в зв'язку з тим, що не можна отримати рішення для затримки в кінцевому вигляді в загальному випадку при довільних законах розподілів вхідного потоку і часу обслуговування. Тому в сучасній теорії телетрафіка важливі дослідження таких систем для окремих випадків вхідних розподілів.

Мета роботи. Отримання рішення для середньої затримки в черзі в замкнутій формі для систем масового обслуговування зі звичайними і з зсунутими вправо від нульової точки розподілами в сталому режимі.

Метод. Для вирішення поставленого завдання був використаний класичний метод спектрального розкладання рішення інтегрального рівняння Ліндлі. Цей метод дозволяє отримати рішення для середнього часу очікування для розглянутих систем в замкнутій формі. Метод спектрального розкладання рішення інтегрального рівняння Ліндлі грає важливу роль в теорії систем $\mathrm{G} / \mathrm{G} / 1$. Для практичного застосування отриманих результатів було використано відомий метод моментів теорії ймовірностей.

Результати. Вперше отримано спектральні розкладання рішення інтегрального рівняння Линдли для систем зі звичайними та з зсунутими гиперекспониціональне і гиперерлангівське розподілами, за допомогою якого виведено розрахункове вираз для середньої затримки в черзі в замкнутій формі.

Висновки. Доведено, що спектральні розкладання рішення інтегрального рівняння Линдли для розглянутих систем збігаються, тому формули для середньої затримки також будуть збігатися. Показано, що в системах з запізненням у часі середній час очікування менше, ніж в звичайних системах. Отримане розрахункове вираз для часу очікування розширює $\mathrm{i}$ доповнює відому незавершену формулу теорії масового обслуговування для середньої затримки для систем 3 довільними законами розподілів вхідного потоку і часу обслуговування. Такий підхід дозволяє розрахувати середньої затримки для зазначених систем в математичних пакетах для широкого діапазону зміни параметрів трафіку. Крім середньої затримки, такий підхід дає можливість також визначити моменти вищих порядків часу очікування. 3 огляду на той факт, що варіація затримки пакетів (джиттер) в телекомунікації визначається як дисперсія часу очікування від його середнього значення, то джиттер можна буде визначити через дисперсію затримки.

КЛЮЧОВІ СЛОВА: система з запізненням, зсунуті розподілу, перетворення Лапласа, інтегральне рівняння Линдли, метод спектрального розкладання.

\section{УДК 621.391.1:621.395 \\ МОДЕЛИ ЗАДЕРЖКИ НА БАЗЕ СИСТЕМ С ОБЫЧНЫМИ И СДВИНУТЫМИ ГИПЕРЭКСПОНЕНЦИАЛЬНЫМ И ГИПЕРЭРЛАНГОВСКИМ ВХОДНЫМИ РАСПРЕДЕЛЕНИЯМИ}

Тарасов В. Н. - д-р техн. наук, профессор, заведующий кафедрой программного обеспечения и управления в технических системах Поволжского государственного университета телекоммуникаций и информатики, РФ.

Бахарева Н. Ф. - д-р техн. наук, профессор, заведующая кафедрой информатики и вычислительной техники Поволжского государственного университета телекоммуникаций и информатики, РФ.

Актуальность. В теории массового обслуживания исследования систем произвольными законами распределений входного потока и времени обслуживания актуальны в связи с тем, что нельзя получить решения для времени ожидания в конечном виде в общем случае при произвольных законах распределений входного потока и времени обслуживания. Поэтому в современной теории телетрафика важны исследования таких систем для частных случаев входных распределений.

Цель работы. Получение решения для средней задержки в очереди в замкнутой форме для систем массового обслуживания с обычными и с сдвинутыми вправо от нулевой точки гиперэкспоненциальным и гиперэрланговским распределениями в установившемся режиме.

Метод. Для решения поставленной задачи использован классический метод спектрального разложения решения интегрального уравнения Линдли. Данный метод позволяет получить решение для средней задержки для рассматриваемых систем в замкнутой форме. Метод спектрального разложения решения интегрального уравнения Линдли играет важную 
роль в теории систем $\mathrm{G} / \mathrm{G} / 1$. Для практического применения полученных результатов использован известный метод моментов теории вероятностей.

Результаты. Впервые получено спектральное разложение решения интегрального уравнения Линдли для систем с обычными и с сдвинутыми гиперэкспоненциальным и гиперэрланговским распределениями, с помощью которого выведено расчетная формула для средней задержки в очереди в замкнутой форме.

Выводы. Доказано, что спектральные разложения решения интегрального уравнения Линдли для рассматриваемых систем совпадают, поэтому формулы для средней задержки также будут совпадать. Показано, что в системах с запаздыванием во времени средняя задержка меньше, чем в обычных системах. Полученное расчетное выражение для времени ожидания расширяет и дополняет известную незавершенную формулу теории массового обслуживания для среднего времени ожидания для систем с произвольными законами распределений входного потока и времени обслуживания. Такой подход позволяет рассчитать среднее время ожидания для указанных систем в математических пакетах для широкого диапазона изменения параметров трафика. Кроме среднего времени ожидания, имеется возможность определения и моментов высших порядков времени ожидания. Учитывая тот факт, что вариация задержки пакетов (джиттер) в телекоммуникациях определяется как разброс времени ожидания вокруг его среднего значения, то джиттер можно будет определить через дисперсию времени ожидания.

КЛЮЧЕВЫЕ СЛОВА: система с запаздыванием, сдвинутые распределения, преобразование Лапласа, интегральное уравнение Линдли, метод спектрального разложения.

\section{ЛІТЕРАТУРА / ЛИТЕРАТУРА}

1. Kleinrock L. Queueing Systems, Vol. I: Theory / L. Kleinrock. - New York : Wiley, 1975. -417 p.

2. Tarasov V. N. The average waiting time in a $\mathrm{H}-2 / \mathrm{H}-2 / 1$ queueing system with delay / V. N. Tarasov, E. G. Akhmetshina // Journal of Samara State Technical University, Ser. Physical and Mathematical Sciences. - 2018. - No. 2. - P. 702-713.

3. Tarasov V. N. The analysis of two queuing systems HE2/M/1 with ordinary and shifted input distributions / V. N. Tarasov // Radio Electronics, Computer Science, Control. - 2019. Vol. 49, No. 2. - P. 71-79. DOI: 10.15588/1607-3274-2019-2-8

4. Tarasov V. N. Queueing systems with delay / V. N. Tarasov // Radio Electronics, Computer Science, Control. - 2019. Vol. 50, No. 3. - P. 71-79. DOI: 10.15588/1607-3274-2019-3-7

5. Tarasov V. N. Comparative analysis of two queuing systems M/HE2/1 with ordinary and with the shifted input distributions / V. N. Tarasov, N. F. Bakhareva // Radio Electronics, Computer Science, Control. - 2019. - Vol. 51. - No. 4. - P. 50-58. DOI: $10.15588 / 1607-3274-2019-4-5$

6. Tarasov V. N. Analysis of H-2/E-2/1 system and her of the analog with shifted input distributions / B. H. Tарасов // Radio Electronics, Computer Science, Control. - 2020. - Vol. 52, No. 1. - P. 90-97. DOI: 10.15588/1607-3274-2020-1-10

7. Tarasov V. N. Model of teletraffic based on queueing systems E-2/HE2/1 with ordinary and shifted input distributions / V. N. Tarasov, N. F. Bakhareva // Radio Electronics, Computer Science, Control. - 2020. - Vol. 53, No. 2. - P. 65-74 DOI: $10.15588 / 1607-3274-2020-2-7$

8. Brannstrom N. A Queueing Theory analysis of wireless radio systems / N. Brannstrom - Appllied to HS-DSCH. Lulea university of technology, 2004. -79 p.

9. Whitt W. Approximating a point process by a renewal process: two basic methods / W. Whitt // Operation Research. - 1982. № $1 .-$ P. 125-147.

10. Limiting the oscillations in queues with delayed information through a novel type of delay announcement / [S. Novitzky, J. Pender, R. H. Rand, E. Wesson] // Queueing Systems. 2020. - Vol. 95. - P. 281-330. DOI: https://doi.org/10.1007/s11134-020-09657-9

11. Nonlinear Dynamics in Queueing Theory: Determining the Size of Oscillations in Queues with Delay / S. Novitzky, J. Pender, R. H. Rand, E. Wesson // SIAM J. Appl. Dyn. Syst., 18-1. 2019. - Vol. 18, No. 1. - P. 279-311. DOI: https://doi.org/10.1137/18M1170637

12. HTTPS://tools.ietf.org/html/rfc3393. RFC 3393 IP Packet Delay Variation Metric for IP Performance Metrics (IPPM) (дата обращения: 26.02.2016).
13. Myskja A. An improved heuristic approximation for the GI/GI/1 queue with bursty arrivals / A. Myskja // Teletraffic and datatraffic in a Period of Change, ITC-13. Elsevier Science Publishers. - 1991. - P. 683-688.

14. Aliev T. I. Approximation of Probability Distributions in Queuing Models / T. I. Aliev // Scientific and technical bulletin of information technologies, mechanics and optics. - 2013. No. 2. - P. 88-93.

15. Aras A. K. Many-server Gaussian limits for overloaded nonMarkovian queues with customer abandonment / A.K. Aras, X. Chen, Y. Liu // Queueing Systems. - 2018. - Vol. 89, No. 1. - P. 81-125. DOI: https://doi.org/10.1007/s11134-0189575-0

16. Jennings O. B. Comparisons of ticket and standard queues / O. B. Jennings, J. Pender // Queueing Systems. - 2016. Vol. 84, No. 1. - P. 145-202. DOI: https://doi.org/10.1007/s11134-016-9493-y

17. Gromoll H. C., Terwilliger B. \& Zwart B. Heavy traffic limit for a tandem queue with identical service times / H. C. Gromoll, B. Terwilliger, B. Zwart // Queueing Systems. - 2018. Vol. 89, No. 3. - P. 213-241. DOI: https://doi.org/10.1007/s11134-017-9560-z

18. Legros B. M/G/1 queue with event-dependent arrival rates / B. Legros // Queueing Systems. - 2018. - Vol. 89, No. 3. P. 269-301. DOI: https://doi.org/10.1007/s11134-017-9557-7

19. Bazhba M. Queue with heavy-tailed Weibull service times / M. Bazhba, J. Blanchet, C. H. Rhee // Queueing Systems. 2019. - Vol. 93, No. 11. - P. 1-32. DOI: https://doi.org/10.1007/s11134-019-09640-z/

20. Adan I. Special volume on 'Recent Developments in Queueing Theory' of the third ECQT conference / I. Adan, B. D'Auria, O. Kella // Queueing Systems. - 2019. - Vol. 93, No. 1. - P. 1190. DOI: https://doi.org/10.1007/s11134-019-09630-1

21. Adan I. Special volume on 'Recent Developments in Queueing Theory' of the third ECQT conference: part 2 / I. Adan, B. D’Auria, O. Kella // Queueing Systems. - 2019. - P. 1-2. DOI: https://doi.org/10.1007/s11134-019-09637-8

22. Tibi D. Martingales and buffer overflow for the symmetric shortest queue model / D. Tibi // Queueing Systems. - 2019. Vol. 93. - P. 153-190. DOI: 10.1007/s11134-019-09628-9

23. Jacobovic R. Asymptotic independence of regenerative processes with a special dependence structure / R. Jacobovic, O. Kella // Queueing Systems. - 2019. - Vol. 93. - P. 139-152. DOI: $10.1007 / \mathrm{s} 11134-019-09606-1$

24. Wang L. Fluid and diffusion models for a system of taxis and customers with delayed matching / L. Wang, V. Kulkarni // Queueing Systems. - 2020. - Vol. 96. - P. 101-131. DOI: 10.1007/s11134-020-09659-7 